Jerusalem: 13-18 September 1981

PRESIDENT OF CONGRESS

James V. Neel

VICE PRESIDENT OF CONGRESS

Arieh Szeinberg

\section{SCIENTIFIC COMMITTEE}

Arno G. Motulsky, Chairman

Walter F. Bodmer

Jean Frezal

Joshua Lederberg

Charles R. Scriver

\section{ORGANIZING COMMITTEE}

Batsheva Bonné-Tamir, Chairperson

Tirza Cohen, Treasurer

Avinoam Adam

Richard M. Goodman

Giora Simchen
INTERNATIONAL FINANCE COMMITTEE

M.M. Cohen, U.S.A., Chairman

C.S. Bartsocas, Greece

P. Beighton, S. Africa

K. Berg, Norway

N.P. Bochkov, U.S.S.R.

D. Bootsma, Netherlands

J. de Grouchy, France

A. de la Chappelle, Finland

M.A. Ferguson-Smith, U.K.

N. Hashem, Egypt

R.L. Kirk, Australia

R. Lisker, Mexico

J. Mohr, Denmark

P. Parisi, Italy

L.E. Rosenberg, U.S.A.

F.M. Salzano, Brazil

L.D. Sanghvi, India

W. Schmid, Switzerland

L. Siminovitch, Canada

H. Van den Berghe, Belgium

F. Vogel, Germany

\title{
PRELIMINARY THEMES
}

\section{Lectures and Plenary Sessions}

Modern idea of the Human Gene

Linkage in Man

Antiquity of Man
The New Genetics: cloning, gene visualization and regulation

Genetics of Common Disease

\section{Round Tables and Poster Sessions}

Teaching of Human Genetics

Models of Chromosome Structure

Delivery of Genetic Services

Insights from Primitive Populations

Statistical Methodology as applied to Genetic Data

Polymorphism and Disease

Treatment of Genetic Diseases

Red Cell Membrane Defects

Quantitative Genetics
Symposia in the areas of:

Antenatal Diagnosis

Molecular Cytogenetics

HLA and Disease

Biological Aspects of Behavioral Genetics

Monitoring for Environmental Mutagenesis

Clinical Genetics

Population Aspects of Restriction Enzymes and

Detectable Polymorphisms

Molecular Mechanism of Enzymatic Defects

Somatic Cell Genetics: new techniques of

genetic mapping

Genetics of Cancer

\section{TRAVEL AND ACCOMMODATION}

KENES TOURS

P.O. Box 16271

Tel Aviv, Israel

Telephone: (03) 289226/7 Telex: 341171 KENES IL
CONGRESS SECRETARIAT

P.O. Box 16271, Tel Aviv, Israel

Telephone: (03) 255367

Telex: 341171 KENS IL. 